\title{
Empati Terhadap Perilaku Altruisme Pada Guru Anak Berkebutuhan Khusus
}

\author{
Rani $^{1}$, Dinda Septiani' ${ }^{2}$, Auliya Syaf ${ }^{3}$ \\ Fakultas Psikologi Universitas Abdurrab ${ }^{123}$ \\ birgitaraniayu@gmail.com
}

\begin{abstract}
Abstrak
Empati adalah kemampuan atau keadaan mental seseorang untuk dapat menyadari dan memahami perasaan orang lain dengan bahasa verbal atau nonverbal. Kemampuan yang muncul meliputi kapasitas afektif, untuk merasakan perasaan dan kemampuan kognitif orang lain untuk memahami perasaan sertasudut pandang orang lain. Altruisme adalah motif untuk meningkatkan kesejahteraan orang lain tanpa memikirkan kepentingan diri sendiri. Tujuan dari penelitian ini adalah untuk mengetahui hubungan antara empati dan perilaku altruisme pada Guru Kebutuhan Anak di Pekanbaru. Penelitian ini adalah penelitian kuantitatif dengan pendekatan korelasional. Subjek dalam penelitian ini adalah guru anak-anak berkebutuhan khusus di Pekanbaru dengan jumlah sampel 64 orang. Teknik pengumpulan data dalam penelitian ini menggunakan dua skala psikologis, yaitu skala empati dan skala altruisme, dengan menggunakan teknik sampling kuota. Pengujian hipotesis menggunakan analisis korelasi Pearson Product Moment. Hasil koefisien korelasi menghasilkan $\mathrm{r}=0,558$ dengan taraf signifikansi $\mathrm{p}=0,000(\mathrm{p}<0,05)$ yang artinya ada hubungan antara empati dan perilaku altruisme pada Guru Anak Berkebutuhan Khusus di Pekanbaru. Empati yang tinggi akan meningkatkan perilaku altruism, dan sebaliknya.
\end{abstract}

Kata Kunci : empati, altruism, berkebutuhan khusus

\begin{abstract}
Empathy is the ability or mental state of a person to be able to realize and understand the feelings of others by verbal or nonverbal language that arises which includes affective capacity to feel other people's feelings and cognitive capacity to understand the feelings and points of view others. Altruism is a motive for increasing the welfare of others without thinking of self-interest. The purpose of this study was to determine the relationship between empathy and altruism behavior in Teachers of Children Special Needs in Pekanbaru. This research is quantative research with a correlational approach. Subject in this study were teachers of children with special needs in Pekanbaru with a total sample of 64 people. Data collection technique in this study used two psychological scales, namely empathy scale and altruism scale, by sampling using quota sampling techniques. Hypothesis testing uses Pearson Product Moment correlation analysis. The results of the correlation coefficient yield $\mathrm{r}=0.558$ with a significance level of $p=0.000(p<0.05)$ which means that there is a relationship between empathy and altruism behavior in Teachers of Children with Special Needs in Pekanbaru. high empathy will improve alt ruism behavior, and vice versa.
\end{abstract}

Keywords: empathy, altruism, special needs

\section{PENDAHULUAN}

Anak berkebutuhan khusus adalah sebutan bagi mereka yang mengalami keadaan diri berbeda dari anak-anak pada umumnya (Diahwati \& Hanurawan, 2016). Jumlah anak berkebutuhan khusus di peroleh peneliti berdasarkan Kementrian Pendidikan dan Kebudayaan tahun 2017/2018 sejumlah 21,2 ribu siswa penyandang kebutuhan khusus yang mengenyam bangku sekolah (Lokadata, 2018). Dari data tersebut jumlah anak berkebutuhan khusus mengalami peningkatan setiap tahunnya. 
Dalam Peraturan Menteri Pendidikan Nasional Indonesia Nomor 70 Tahun 2009 juga disebutkan bahwa peserta didik yang memiliki kelainan fisik, emosional, mental, sosial dan atau memiliki potensi kecerdasan dan atau bakat istimewa perlu mendapatkan layanan pendidikan yang sesuai dengan kebutuhan asasinya (Indriawati, 2013). Berdasarkan uraian Undang-Undang di atas maka dapat disimpulkan bahwa anak berkebutuhan khusus berhak mendapatkan pendidikan.

Tujuan dari pendidikan anak berkebutuhan khusus adalah supaya mereka dapat hidup mandiri dan mengembangkan potensi yang dimiliki, sehingga tidak tergantung dengan orang lain (Miftahudin, 2014). Pelayanan pendidikan dalam upaya mengembangkan potensi yang dimiliki anak secara optimal membutuhkan tenaga pendidik atau yang sering disebut dengan guru (Elisa \& Wrastari, 2013). Tugas guru untuk anak berkebutuhan khusus tidaklah sama dengan guru pada anak normal. Beban yang harus ditempuh lebih berat, karena mereka harus berhadapan dengan anak yang memiliki kebutuhan khusus dengan karakteristik berbeda-beda. Hal tersebut setara dengan pernyataan Rosyadi (dalam Firmansyah \& Widuri, 2014) bahwa menjadi guru anak berkebutuhan khusus sangat berbeda dengan guru di sekolah umum, selain harus sabar dan juga tekun dalam menghadapi anak didiknya, guru harus ikhlas dalam memberikan pelajaran, guru anak berkebutuhan khusus harus menganggap anak didiknya sebagai anak sendiri dan ketika sedang mengajar harus mampu membaca apa yang diinginkan oleh anak didiknya. Guru harus tidak mementingkan diri sendiri di banding murid.

Suatu minat yang tidak mementingkan diri sendiri dalam menolong individu dalam ilmu psikologi disebut altruisme (Robet, 2013). Altruisme adalah tindakan suka rela yang dilakukan oleh seseorang atau sekelompok orang untuk menolong orang lain tanpa mengharapkan imbalan apapun (kecuali mungkin perasaan telah melakukan kebaikan) (Myers, 2012). Myers (2012) membagi perilaku altruisme kedalam tiga aspek yaitu memberikan perhatian terhadap orang lain, membantu orang lain dan meletakkan kepentingan orang lain diatas kepentingan sendiri.

Guru yang memiliki altruisme dapat mendorong anak untuk dapat berkembang dengan baik. Pernyataan tersebut didukung oleh penelitian Laila dan Asmarany (2015) yang telah membuktikan bahwa perilaku altruistik yang dimiliki guru mampu meningkatkan motivasi anak. Berlainan dengan kondisi tersebut, guru yang memiliki altruisme yang rendah dapat memberikan kesan buruk bagi anak, sehingga motivasi anak untuk berkembang buruk. Salah satu faktor yang mempengaruhi perilaku altruisme adalah adanya empati yaitu kemampuan seseorang untuk ikut merasakan perasaan atau pengalaman orang lain (Myers, 2012).

Hogan (dalam Howe, 2015) melihat empati sebagai "pemahaman intelektual atau imajinatif tentang kondisi atau keadaan pikiran orang lain". Adapun aspek-aspek empati menurut Davis (1983) yaitu dilihat dari komponen kognitif terdiri dari Perspective Taking (PT) dan Fantacy (FS), sedangkan komponen afektif terdiri dari Empathic Cancern (EC) dan Personal Distress (PD). Semakin tinggi empati maka guru tersebut akan makin mampu "feeling in", mengupayakan untuk memahami kondisi orang lain, baik itu anak didik atau rekan kerja. Pemahaman tersebut dapat membantu guru dalam proses pengolahan kelas berdasarkan kebutuhan dan kelebihan muridnya serta menjalin hubungan baik dengan rekan kerjanya (Sjabadhyni, dalam Raharjaningtyas, 2013).

Untuk dapat menjadikan siswa tersebut mandiri dan dapat melakukan apa yang orang normal lakukan, guru tidak hanya sekedar mengajar dan memberikan materi pelajaran disekolah, melainkan pentingnya sikap empati yang ditunjukkan dengan bentuk perilaku untuk dapat mencapai tujuan guru dalam mengajar ABK. Selain itu, empati juga akan memberikan 
kesan nyaman bagi ABK untuk belajar (Asih \& Pratiwi, 2010). Berdasarkan fenomena yang terjadi bahwa terdapat kurangnya kemampuan guru dalam memahami dan merasakan. Oleh karenanya tujuan dari penelitian ini adalah untuk meneliti hubungan antara empati dengan perilaku altruisme pada guru anak berkebutuhan khusus di Pekanbaru.

\section{METODE}

Subjek dalam penelitian ini sebanyak 64 orang guru anak berkebutuhan khusus. Teknik pengambilan subjek menggunakan sampling kuota. Data dikumpulkan dengan menggunakan 2 skala, yaitu skala empati dan skala altruism. Skala empati yang diadaptasi dari skala IRI (Interpersonal Reactivity Index) Davis (1983) berdasarkan aspek-aspek diantaranya, yaitu Perspective Taking, Fantacy, Empathic Cancern, dan Personal Distress dengan nilai reliabilitas $\alpha$ sebesar 0,781. Koefisien korelasi bergerak dari dari (r) 0,362 sampai 0,741. Skala ini disusun dengan model skala likert yang berjumlah 14 aitem. Masing-masing aitem disediakan 5 kategori pilihan jawaban, yaitu 1 (Sangat Sesuai), sampai dengan 5 (Sangat Tidak Sesuai). Koefisien reliabilitas skala empati adalah sebesar 0,875 dari keempat aspek yaitu perspective taking sebesar 0,661, fantasy sebesar 0,829, empathic concern 0,137 , dan personal distress sebesar 0,578. Skala perilaku altruisme terdiri dari 32 aitem yang disusun peneliti berdasarkan aspek dalam teori Myers (2012) diantaranya, yaitu memberikan perhatian terhadap orang lain, membantu orang lain, dan meletakkan kepentingan orang lain diatas kepentingan sendiri. Skala ini disusun dengan model skala likert yang berjumlah 44 aitem. Masing-masing aitem disediakan 5 kategori pilihan jawaban, yaitu 1 (Sangat Sesuai), sampai dengan 5 (Sangat Tidak Sesuai). Koefisien korelasi bergerak dari (r) 0,256 sampai 0,765. Sedangkan koefisien reliabilitas perilaku altruisme sebesar 0,876.

\section{HASIL}

Tabel 1. Kategorisasi empati

\begin{tabular}{cccc}
\hline Kategori & Skor & frekuensi & persentase \\
\hline Rendah & $X<19$ & 1 & $1,6 \%$ \\
\hline Sedang & $19 \leq X<37$ & 44 & $68,8 \%$ \\
\hline Tinggi & $X \geq 37$ & 19 & $29,7 \%$ \\
\hline Jumlah & & 64 & $100 \%$ \\
\hline
\end{tabular}

Bedasarkan kategori tabel 1 di atas, hasil perhitungan menunjukkan dari 64 sampel penelitian terdapat 1 orang $(1,6 \%)$ empati pada kategori rendah, 44 orang $(68,8 \%)$ empati pada kategori sedang, dan untuk 19 orang $(29,7 \%)$ empati pada kategori tinggi.

Tabel 2. Kategorisasi Altruisme

\begin{tabular}{cccc}
\hline Kategori & Skor & frekuensi & persentase \\
\hline Rendah & $X<75$ & 0 & $0 \%$ \\
\hline Sedang & $75 \leq X<117$ & 43 & $67,2 \%$ \\
\hline Tinggi & $X \geq 117$ & 21 & $32,8 \%$ \\
\hline Jumlah & & 64 & $100 \%$ \\
\hline
\end{tabular}


Bedasarkan kategori tabel 2 di atas, hasil perhitungan menunjukkan dari 64 sampel penelitian terdapat 0 orang $(0 \%)$ altruisme pada kategori rendah, 43 orang $(67,2 \%)$ altruisme pada kategori sedang, dan untuk 21 orang $(32,8 \%)$ altruisme pada kategori tinggi.

Hasil uji normalitas menggunakan Kolmogorov smirnov. Variabel empati terhadap perilaku altuisme pada guru anak berkebutuhan khusus di Pekanbaru diperoleh, nilai $p$ sebesar 0,976 dengan $(p>0,05)$ dan data variabel perilaku altruisme guru anak berkebutuhan khusus nilai $p$ sebesar 0,292 dengan $(p>0,05)$. Dapat disimpulkan hasil yang diperoleh dari sebaran dalam penelitian menunjukkan adanya distribusi yang normal. Uji linieritas diperoleh bahwa $F=22,924$ dari $p=0,000(<0,05)$. Signifikansi kurang dari 0,05, maka dapat disimpulkan bahwa antara variabel empati dan perilaku altruisme terdapat hubungan yang linear.

Hasil penelitian menggunakan teknik koefisien korelasi product moment pearson menunjukkan angka probabilitas $p=0,000(p<0,05)$ yang artinya ada hubungan yang signifikan antara empati dengan perilaku altruisme pada guru anak berkebutuhan khusus di Pekanbaru. Sementara itu, nilai $(r)=0,558$, berada pada interval $0,40-0,599$, hal ini menunjukkan bahwa tingkat hubungan sedang antara kedua variabel dan memiliki arah hubungan yang positif, yaitu semakin tinggi empati guru anak berkebutuhan khusus maka semakin tinggi pula altruisme guru anak berkebutuhan khusus. Dengan demikian hipotesis yang diajukan pada penelitian ini diterima.

Hasil uji regresi linear digunakan dalam penelitian ini untuk melihat sumbangan efektif nilai variabel empati terhadap perilaku altruisme pada guru anak berkebutuhan khusus di Pekanbaru diperoleh nilai $\mathrm{R}$ square sebesar 0,312 nilai tersebut menunjukkan bahwa sumbangan efektif empati terhadap perilaku altruisme pada guru anak berkebutuhan khusus sebesar $31,2 \%$. Hasil uji korelasi tiap aspek dari empati dengan altruisme menggunakan product moment pearson menunjukkan hasil bahwa hubungan antara aspek perspective taking dengan altruisme sebesar $0,443(0,40-0,599)$ berada pada kategori sedang dengan taraf signifikansi 0,000 (signifikan). Hubungan antara fantasy dengan altruisme sebesar 0,465 (0,40 - 0,599) berada pada kategori sedang dengan taraf signifikansi 0,000 (signifikan). Hubungan antara empathic concern dengan altruisme sebesar 0,444 $(0,40$ - 0,599) berada pada kategori sedang dengan taraf signifikansi 0,000 (signifikan). Hubungan antara personal distress dengan altruisme sebesar 0,306 $(0,20-0,399)$ berada pada kategori rendah dengan taraf signifikansi 0,014 (signifikan). Hal ini berarti aspek perspective taking, fantasy, empathic concern dan personal distress memiliki hubungan yang signifikan dengan altruism.

Tabel 3. Analisis korelasi per aspek

\begin{tabular}{ccrc}
\hline Aspek Empati & Korelasi & Signifikansi & Ket \\
\hline Perspective Taking & $0,443^{* *}$ & 0,000 & Signifikansi \\
\hline Fantasy & $0,465^{* *}$ & 0,000 & Signifikansi \\
\hline Empathic Concern & $0,444^{*}$ & 0,000 & Signifikansi \\
\hline Personal Distress & $0,306^{*}$ & 0,014 & Signifikansi \\
\hline
\end{tabular}

\section{HASIL DAN PEMBAHASAN}

Penelitian ini bertujuan untuk mengetahui hubungan antara empati dengan perilaku altruisme pada guru anak berkebutuhan khusus. Hasil dari penelitian ini menunjukkan bahwa 
empati dan perilaku altruisme memiliki hubungan yang positif yaitu semakin tinggi empati pada guru anak berkebutuhan khusus, maka semakin tinggi pula perilaku altruisme guru anak berkebutuhan khusus. Hasil penelitian ini sesuai dengan hipotesis yang diberikan oleh peneliti yaitu empati dan perilaku altruisme memiliki hubungan yang positif. Maka, dengan demikian hipotesis yang diajukan pada penelitian ini diterima.

Temuan penelitian didukung oleh Hapsari (2016) yang mengatakan individu yang memiliki rasa empati yang tinggi akan mampu berperilaku altruisme dalam kesehariannya, ketika individu sudah dapat merasakan bagaimana keadaan orang lain, maka akan timbul perasaan simpati atau rasa kepedulian kepada orang lain. Empati dapat dikaitkan dengan teori kepribadian Carl Rogers. Teori ini sangat bersifat klinis beliau memandang kesehatan mental sebagai proses perkembagan hidup ilmiah. Perhatian utama rogers adalah kemampuan meletakkan diri sendiri dalam posisi orang lain dan menghayati pengalaman tersebut serta untuk melihat situasi dari sudut pandang orang lain. Rogers (1959) menawarkan dua konsepsi dari empati. Pertama, melihat kerangka berpikir internal orang lain secara akurat dengan komponen-komponen yang saling berhubungan. Kedua, dalam memahami orang lain tersebut, individu seolah-olah masuk dalam diri orang lain sehingga bisa merasakan dan memahami orang lain tersebut. Berdasarkan hal tersebut menunjukkan bahwa dengan adanya empati maka seseorang akan memberikan bantuan kepada orang lain, memberikan bantuan kepada orang lain merupakan salah satu cakupan dari altruisme (Myers, 2012).

Berdasarkan uji korelasi setiap aspek empati dengan altruisme diketahui bahwa aspek perspective taking, fantasy, empathic concern dan personal distress memiliki hubungan yang signifikan dengan altruisme. Hasil penelitian ini didukung oleh penelitian Maner, Luce, Neuberg dan Cialdini (2002) yang mengatakan kunci pokok dari perspective taking (pengambilan perspektif) terletak pada kemampuan seseorang dalam mengoptimalkan pikirannya untuk memahami kondisi orang lain, melalui pemaknaan sikap dan perilaku yang dilihatnya, adanya perspective taking seseorang akan memberikan bantuan dan mengedepankan kepentingan orang lain daripada kepentingannya sendiri merupakan cakupan dari aspek altruisme.

Aspek fantacy (Imajinasi) merupakan kemampuan seseorang untuk mengubah diri mereka secara imajinatif dalam mengalami perasaan dan tindakan dari karakter khayal (membayangkan) dalam buku, film atau cerita yang dibaca dan di tontonnya. Fantasy merupakan aspek yang berpengaruh pada reaksi emosi terhadap orang lain dan menimbulkan perilaku menolong (altruisme) (Arum, (2018).

Aspek empathic concern merupakan perasaan yang berorientasi pada orang lain berupa simpati, kasihan, peduli dan perhatian terhadap orang lain yang mengalami kesulitan, Aspek ini berhubungan secara positif dengan rekasi emosional, perilaku menolong pada orang lain dan merupakan cerminan dari perasaan kehangatan yang erat kaitannya dengan kepekaan dan kepedulian terhadap orang lain (altruisme) (Oswald, 1996).

Aspek personal distress merupakan orientasi seseorang terhadap dirinya sendiri yang berupa perasaan cemas dan kegelisahan dalam menghadapi setting (situasi) interpersonal yang tidak menyenangkan. Penelitian yang pernah dilakukan oleh Thomas (2012) menyebutkan bahwa kondisi personal distress berpengaruh pada bagaimana seseorang memandang kualitas hidupnya. Seseorang yang mengalami personal distress, menunjukkan bahwa orang tersebut memiliki kesadaran untuk menyayangi orang lain, terutama dalam membantu mereka untuk menyelesaikan masalahnya. Hal ini menunjukkan bahwa dengan adanya personal distress 
maka seseorang akan memberikan perhatian dan memberikan bantuan kepada orang lain merupakan cakupan aspek altruisme.

Pada hasil penelitian empati guru anak berkebutuhan khusus berada pada kategori sedang didukung oleh penelitian Istiqomah (2015) selain mengajar berdasarkan kurikulum yang ada, guru anak berkebutuhan khusus juga harus memiliki empati yang tinggi, karena tidak semua anak berkebutuhan khusus dapat melakukan hal-hal sulit secara mandiri, sehingga guru anak berkebutuhan khusus perlu memiliki rasa empati dalam membantu siswa untuk lebih berkembang sesuai dengan kemampuannya. Pada penelitian Raharjaningtyas dan Masykur (2012) pada dasarnya empati memiliki peran dalam menentukan tingkat komitmen profesi pada guru Sekolah Luar Biasa, guru yang mampu memahami apa yang muridnya rasakan, memahami perspektif muridnya dan menyelaraskan diri dengan berbagai tipe individu dapat lebih mengidentifikasi profesi dan mendukung nilai-nilai dari profesi mereka.

Temuan selanjutnya altruisme dibedakan berdasarkan aspek keinginan membatu orang lain yang dibedakan atas dasar diri sendiri dan orang lain, ditemukan bahwa keinginan diri sendiri berada pada kategori tinggi. Seperti pada penelitian Laila dan Asmarany (2015) faktor yang menyebabkan subjek menjadi relawan anak berkebutuhan khusus adalah karena adanya keinginan dalam diri subjek untuk selalu menebar kebaikan kepada orang yang membutuhkan sehingga memunculkan kepuasan pada diri subjek setelahnya.

Hasil penelitian ini menunjukkan sumbangan efektif empati terhadap perilaku altruisme pada guru anak berkebutuhan khusus di Pekanbaru sebesar 32,1\%. Sejalan dengan penelitian Fatimah (2015) faktor faktor yang mempengaruhi altruisme pada guru anak berkebutuhan khusus yaitu Empati, suasana hati, meyakini keadilan dunia, sosiobiologis, dan situsional.

Hasil dari penelitian ini menunjukkan tidak adanya perbedaan altruisme pada laki-laki dan perempuan. Hasil mengungkapkan bahwa laki-laki memiliki altruime lebih tinggi dari pada perempuan. Menurut Olukayoda dan Emmanuel (2014) Ketika berurusan dengan orang lain terungkap bahwa laki-laki yang umum membantu daripada perempuan, sesuai dengan peran tradisionalnya sebagai pelindung, laki- laki lebih mungkin memberi bantuan dibandingkan perempuan, dan perempuan lebih mungkin mendapatkan pertolongan dibandingkan laki-laki karena laki-laki dianggap lebih kuat dibandingkan perempuan.

\section{SIMPULAN}

Berdasarkan hasil penelitian dan pembahasan maka dapat dilihat bahwa antara variabel empati dengan variabel perilaku altruisme pada guru anak berkebutuhan khusus di Pekanbaru. Berdasarkan analisa data dengan menggunakan teknik korelasi Product Moment Pearson menunjukkan ada hubungan yang signifikan antara empati dengan perilaku altruisme. Angka koefisien korelasi sebesar 0,558, hal ini menunjukkan hubungan empati dan perilaku altruisme guru anak berkebutuhan khusus pada tingkat sedang. Arah hubungannya adalah positif, yang artinya semakin tinggi empati guru anak berkebutuhan khusus maka semakin tinggi perilaku altruisme guru anak berkebutuhan khusus, sebaliknya semakin rendah empati guru anak berkebutuhan khusus maka semakin rendah perilaku altruisme guru anak berkebutuhan khusus.

\section{DAFTAR PUSTAKA}

Arum, A. P. (2018). Hubungan antara Empati dan Religiusitas dengan Altruisme pada 
Remaja. Jurnal Psikologi, 1(2), 23-45.

Asih, G. Y., \& Pratiwi, M. M. S. (2010). Perilaku Prososial ditinjau dari Empati dan Kematangan emosi. 1(1), 33-42.

Ayooluwa, O., \& Emmanuel Oyetunji. (2014). Influence of Gender, Spiritual Involvement/Belief and Emotional Stability on Prosocial Behavior among Some Nigerian Drivers. Canadian Social Science, 10(1), 121-127. https://doi.org/10.3968/j.css.1923669720141001.3919

Davis, M. H. (1983). Measuring individual differences in empathy: Evidence for a multidimensional approach. Journal of Personality and Social Psychology, 44(1), 113126. https://doi.org/10.1037/0022-3514.44.1.113

Diahwati, R., \& Hanurawan, F. (2016) Keterampilan Sosial Siswa Berkebutuhan Khusus Di Sekolah Dasar Inklusi. Jurnal psikologi perkembangan dan pendidikan, 1(8), 16121620 .

Elisa, S., \& Wrastari, A. T. (2013). Sikap Guru Terhadap Pendidikan Inklusi Ditinjau Dari Faktor Pembentuk Sikap. Jurnal Psikologi Perkembangan Dan Pendidikan, 2(1), 1-10. Firmansyah, L., \& Widuri, E. L. (2014). Subjective Well-Being Pada Guru Sekolah Luar Biasa (SLB). Jurnal Psikologi, 2(1), 1-8.

Hapsari, I. I. (2016). Empati Dan Motivasi Kerja Guru. Jurnal Penelitian dan Pengukuran Psikologi, 5(1), 48-56.

Howe, D. (2015). Empati Makna dan Pentingnya. Yogyakarta: Pustaka Pelajar.

Indriawati, P. (2013). Implementasi Kebijakan Tugas Guru Pembimbing Khusus pada Pendidikan Inklusif di SD Negeri se-Kecamatan Junrejo Batu. Jurnal Kebijakan dan Pengembangan Pendidikan, 1(1), 49-54.

Istiqomah, D. P. (2015). Dinamika Empati Guru Anak Berkebutuhan Khusus (ABK) di SDLB Putra Jaya Malang. Jurnal Psikologi, I(2), 23-44.

Laila, K. N., \& Asmarany, A. I. (2015). Altruisme pada Relawan Perempuan yang Mengajar Anak Berkebutuhan Khusus di Yayasan Anak Jalanan Bina Insan Mandiri. Jurnal Psikologi, 8(1), 1-7.

Lokadata (2018). Siswa penyandang disabilitas berdasarkan provinsi. Beritagar.id. https://lokadata.beritagar.id/chart/preview/siswa-penyandang-disabilitas-berdasarkanprovinsi-1520847488. diakses pada tanggal 19 April 2019.

Maner, J. K., Luce, C. I., Neuberg, S. L., \& Cialdini, R. B. (2002). The Effects of Perspective Taking on Motivations for Helping: Still No Evidence for Altruisme. Personality and Social Psychology Bulletin, 28(11), 1601-1610.

Miftahudin, L. (2014). Evaluasi Pembelajaran Anak Berkebutuhan Khusus (ABK) Di Kelas Inklusif Di SD Plus Darul ’Ulum Jombang. Jurnal Studi Islam, 5(2), 202-228.

Myers, D., G. (2012). Psikologi Sosial Jilid 2. Jakarta: Salemba Humanika.

Raharjaningtyas, N., \& Masykur, A. M. (2013). Hubungan Antara Empati dengan Komitmen Profesi pada Guru SLB Negeri Semarang. Jurnal Psikologi Pendidikan, 2(1), 1-10. 
Robet, R. (2013). Altruisme, Solidaritas, dan Kebijakan Sosial. Jurnal Sosiologi Masyarakat, $18(1), 1-18$.

Sugiyono. (2017). Metode Penelitian Kuantitatif, Kualitatif, dan R\&D. Bandung : Alfabeta. Thomas, J. T. (2012). Does Personal Distress Mediate the Effect of Mindfulness on Professional Quality of Life?. Advances In Social Work, 13(3), 561-585. 